\title{
Uterine segmental aplasia in sheep
}

\author{
Aplasia segmentar uterina em ovelhas

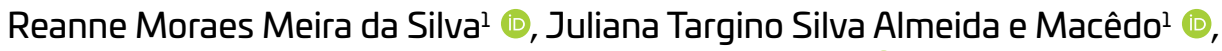 \\ Pedro Miguel Ocampos Pedroso 2* (1)
}

\begin{abstract}
The complete absence of one of the uterine horns, named segmental uterine aplasia or unicorn uterus, occurs due to deficiency in the development of segments of the paramesonephric or Mullerian ducts. It is a congenital or hereditary anomaly of the female reproductive tract caused by recessive genes, which occurrence is unusual. In cows, this malformation was initially called "white heifer disease", comprising an alteration in the Mullerian ducts in association with the white skin gene that causes aplasia of the uterus, cervix and vagina. Two pieces of sheep reproductive system from a slaughterhouse under federal inspection in the state of Bahia, Brazil, were received for pathological diagnosis. The collection, dissection and macroscopic analysis were carried out. In the macroscopic evaluation, uterine segmental aplasia was identified in both cases, with complete absence of the left uterine horns. Both had agenesis of the uterine tubes associated with the absence of internal bifurcation of the uterine horns. Animals that have a unicorn uterus often have reduced fertility which consequently leads to losses to sheep farming.
\end{abstract}

KEYWORDS: malformation, sheep farming, pathology, reproduction, unicorn uterus.

RESUMO: A ausência completa de um dos cornos uterinos, denominada aplasia uterina segmentar ou útero unicorno, ocorre por deficiência no desenvolvimento de segmentos dos ductos paramesonéfricos ou Mullerianos. É uma anomalia congênita ou hereditária do trato reprodutor da fêmea causada por genes recessivos, é incomum a ocorrência. Em vacas, essa malformaçáo foi denominada inicialmente como "white heifers desease" ou doenças das novilhas brancas, é uma alteração dos ductos Mullerianos em associação com o gene da pele branca que provoca aplasia de útero, colo uterino e vagina. Foi recebido duas peças de sistema reprodutor de ovelhas provenientes de abatedouro frigorífico sob inspeção federal no estado da Bahia, Brasil para diagnóstico patológico. Procedeu-se a coleta, dissecação e análise macroscópica. Na avaliaçáo macroscópica, identificou-se nos dois casos aplasia segmentar uterina, com ausência completa dos cornos uterinos esquerdo. Ambos apresentavam agenesia das tubas uterinas associada a ausência de bifurcação interna dos cornos uterinos. Animais que possuem um útero unicorno frequentemente possuem redução da fertilidade e consequentemente podem causar perdas à ovinocultura brasileira.

PALAVRAS-CHAVE: malformação, ovinocultura, patologia, reprodução, útero unicorno.

\section{INTRODUCTION}

The fetal embryonic phase may be affected by disorders of genetic or environmental origin, or in association, named congenital anomalies, that compromise the structure, function or both, of the female reproductive tract (GRADELA et al., 2013). It should be considered that in addition to reproductive changes, they may be associated with urinary malformations (CHANG et al., 2008; MCINTYRE et al., 2010). The complete absence of one of the uterine horns, called segmental uterine aplasia or unicorn uterus, occurs either due to a deficiency in the development of segments of the paramesonephric or Mullerian ducts, to growth interruption or the absence of the duct junction (NASCIMENTO; SANTOS, 2003; SANTOS et al., 2016).

It is more common in cows, sows and female dogs, however, in general, it does not occur frequently. So far there have been no cases of uterine segmental aplasia in sheep in Brazil. This alteration may predispose to the formation of concretions, that is, hysterolites due to the accumulation of endometrial secretion (SANTOS et al., 2016). It is a possibly

\footnotetext{
${ }^{1}$ Programa de Pós-graduação em Ciência Animal nos Trópicos, Universidade Federal da Bahia, Medicina Veterinária, Av. Adhemar de Barros, 500, Ondina, Salvador, Bahia, 40170-110, Brazil.

${ }^{2}$ Laboratório de Patologia Veterinária, Universidade de Brasília, Campus Universitário Darcy Ribeiro, Via L4, Norte, s/n, Brasília, DF, 70.910-970, Brazil.

*Corresponding author: pedrosovet@yahoo.com.br

Received: 05/25/2020. Accepted: 08/31/2020
} 
inherited anomaly caused by recessive genes (NASCIMENTO; SANTOS, 2003). In cows, this malformation was initially referred to as "white heifer disease", as it has a higher occurrence (MCENTEE, 1990). Reproductive efficiency is one of the most important factors that promotes productivity and economic viability of sheep farming, being essential for the development of the herd. However, injuries to the reproductive system have great limitations, which causes a drop in production (CARVALHO JÚNIOR et al., 2010). Thus, diagnosis is necessary to prevent and control the main diseases that affect the sheep reproductive system.

The objective of the present work is to describe the pathological changes in two cases of uterine segmental aplasia in slaughtered sheep.

\section{MATERIAL AND METHODS}

The research was carried out in three slaughterhouses of sheep and goats in the state of Bahia with Federal and State Inspection Services. In the period from July 2018 to February 2019, 1,072 sheared sheep were slaughtered. During slaughter, in evisceration, the sheep reproductive system was sectioned for evaluation and collection of lesions for bacteriological and anatomopathological examination. Collection, dissection, macroscopic analysis were performed.

\section{RESULTS AND DISCUSSION}

During the monitoring of the slaughter of 1,072 sheared sheep, two cases of uterine segmental aplasia were identified $(0.18 \%)$. In the macroscopic evaluation, a complete absence of the left uterine horn was identified in both cases of uterine segmental aplasia (Figure 1). Both had agenesis of the uterine tubes associated with the absence of internal bifurcation of the uterine horns. Additionally, in case 2, the reproductive system had a paraovaric cyst, located close to the ovary, in addition to areas of melanosis in the endometrium. In the ovaries, follicles and corpus luteum were observed, with preserved contralateral uterine tubes and vagina.

The diagnosis of reported cases of uterine segmental aplasia was possible through macroscopic analysis of the reproductive system. In Brazil, no report of a unicorn uterus was found in sheep, but it has been reported in other species such as bitches (PINTO FILHO et al., 2001; PAGLIUCA et al., 2012; AGUIRRA et al., 2014), cat (CORREIA et al., 2018), cow (ANDO et al., 2007) and buffalo (OHASHI et al., 2012; RIBEIRO et al., 2016). In studies with bitches, despite the uterine malformation, there were no changes in the ovaries and the presence of these organs is justified by the embryonic origin different from the uterus (PAGLIUCA et al., 2012; SÔNEGO et al., 2018), which was also verified in the present report.

White heifer disease is an alteration of the Mullerian ducts in association with the white skin gene that causes aplasia of the uterus, cervix and vagina. In the evaluation of

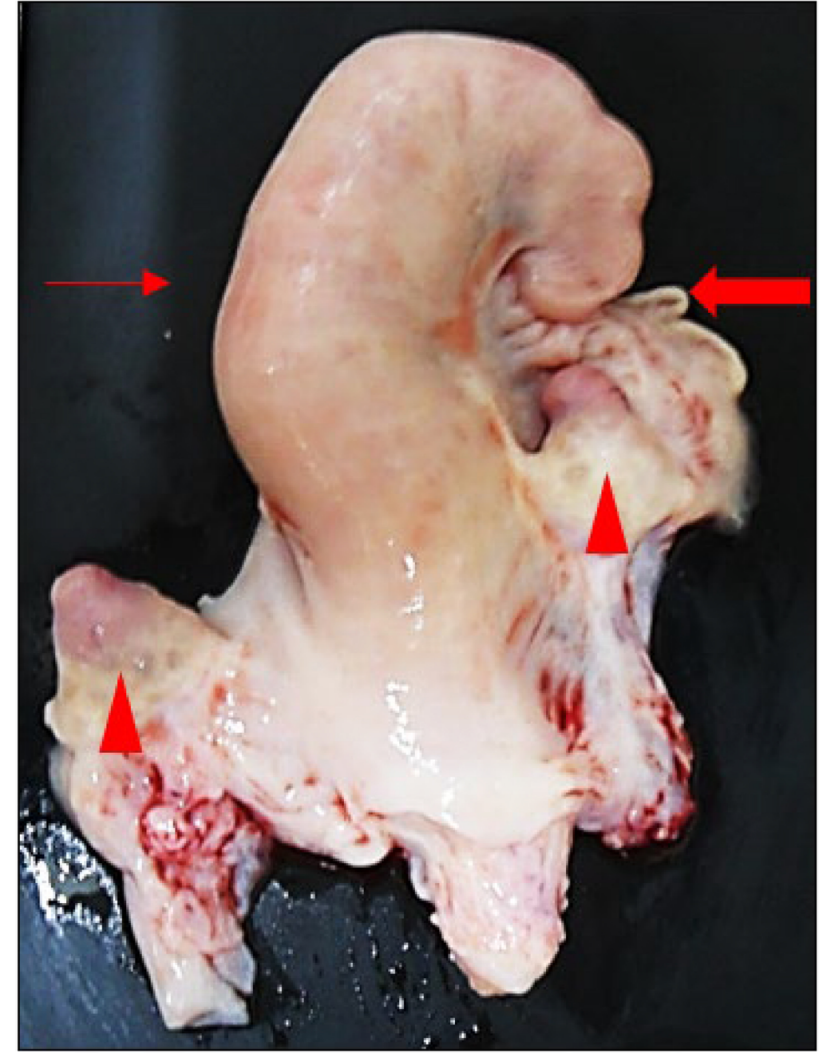

Figure 1. Sheep breeding system. Unicorn uterus. Piece photograph (ventral view), ovaries without macroscopic changes $(-)$, normal right uterine tube $(\Rightarrow$ ) and absence of the left uterine horn ( $\mathbf{\imath})$.

uterine and ovarian blood flow in a Holstein cow with segmental aplasia of the right uterine horn, diagnosed by rectal palpation and transrectal ultrasound, the formation of a corpus luteum in the right ovary was observed during the estrous cycle, in which there was regression and it became persistent, being necessary the application of PGF $2 \alpha$ later to induce ovulation. In this situation of segmental aplasia of a uterine horn, it could cause a reduction in the secretion of PGF $2 \alpha$ by the uterus, which results in a persistent corpus luteum. Regarding the blood flow, the course of uterine blood present on the side of segmental aplasia of the uterine horn is weaker than the contralateral one, which consequently affects the estrous cycle, mainly the regression of the corpus luteum (ANDO et al., 2007).

According to Moriyama et al. (2008), white heifer disease was diagnosed by ultrasonography in 3 animals, case 1 was a 14-month-old heifer with aplasia on both sides of the uterine horn, case 2 was a primiparous cow and case 3 was an 18-month-old heifer with segmental aplasia of the right uterine horn. Despite causing subfertility in the herd, the reproduction was possible in case 2 by artificial insemination in the right ovulatory follicle and corpus luteum in the left ovary, while in case 3 reproduction occurred by embryo transfer. According to Mijten; Kruif (1990), in a herd that 
showed a reduction in fertility, a quarter of the animals presented white heifer disease and the animals affected were descendants of the same bull, characterizing the hereditary character of the alteration.

In buffaloes, an investigation was carried out in 1000 reproductive tracts from slaughterhouses, with 160 showing pathologies and, in one case, uterine segmental aplasia was identified (RIBEIRO et al., 2016). Despite the low incidence, it is important to consider that it is a hereditary alteration. In another research in the same species, 590 reproductive organs were evaluated, in which twelve cases showed different developmental changes, among them two cases of uterine segmental aplasia were identified (OHASHI et al., 2012).

\section{CONCLUSIONS}

As the first report in sheep in Brazil, further investigation will be needed to identify whether they are rare or underdiagnosed cases, due to the fact that it is an anomaly that can cause reduced fertility, and consequently cause losses to Brazilian sheep farming.

\section{ACKNOWLEDGEMENTS}

To the Federal (SIF) and State (SIE) Inspection Service, the slaughterhouse workers, the Laboratories team, the Coordenação de Aperfeiçoamento de Pessoal de Nível Superior (CAPES) for the granting of the first author's scholarship and the Federal University of Bahia (UFBA).

\section{REFERENCES}

AGUIRRA, L. R. V. M. et al. Aplasia de unicorno uterino em cadela - Relato de caso. Revista Brasileira de Medicina Veterinária, v. 36, ก. 4, p. 351-354, 2014.

ANDO, T. et al. Uterine and ovarian blood flow in a holstein friesian cow with aplasia of one uterine horn. The Journal of Veterinary Medical Science, v. 69, n. 4, p. 429-432, 2007.

CARVALHO JÚNIOR, C.A. et al. Agentes infecciosos que podem promover infertilidade em machos da espécie ovina. Revista Brasileira de Reprodução Animal, v. 34, n. 3, p. 160-167, 2010.

CHANG, J. et al. Segmental Aplasia of the uterine horn with ipsilateral renal agenesis in a cat, Journal of Veterinary Medical Science, v. 70, п. 6, p. 64l-643, 2008.

CORREIA, P. R. et al. Agenesia unilateral do corno uterino e ovário direito em gata - Relato de caso. Revista Veterinária e Zootecnia, v. 25, n. 2, p. 1-5, 2018

GRADELA, A. et al. Defeitos Congênitos raros associados à hérnia de Morgagni e à aplasia segmentar de corno uterino em cadela: Relato de caso. Revista Semina: Ciências Agrárias, v. 34, n. 4, p. 1841-1850, 2013.

NASCIMENTO, E. F.; SANTOS, R. L. Patologia da Reprodução dos Animais Domésticos, 2. ed. Rio de Janeiro, Guanabara Koogan, 2003. p. 138.

MCENTEE, K. Reproductive Pathology of Domestic Animals. London, Academic Press, 1990. p. 401.

MCINTYRE, R. L. et al. Developmental uterine anomalies in cats and dogs undergoing elective ovariohysterectomy. Journal of the
American Veterinary Medical Association, Schaumburg, v. 237, n. 5, p. 542-546, 2010.

MIJTEN, P.; DE KRUIF A. White heifer disease as a cause of herd subfertility. Tijdschrift Voor Diergeneeskunde, v. 115, n. 15, p. 736, 1990.

MORIYAMA, C. Case of pregnancy in two cows with unicorn horn of the uterus either by artificial insemination at ipsilateral or embryo transfer at contralateral corpus luteum in the ovary. Reproduction in Domestic Animals, v. 43, n. 3, p. 382-384, 2008.

OHASHI, O. et al. Distúrbios reprodutivos do rebanho bubalino nacional. Ciência Animal, v. 22, n. 1, p. 171-187, 2012.

PACLIUCA, T. C. L.; MARQUES, J. M. V.; FILADELFHO, A. L. Malformações congênitas na ovariohisterectomia em cadelas: útero unicorno - Relato de caso. Revista Científica Eletrônica de Medicina Veterinária, v. 10, n. 19, p. 7-9, 2012.

PINTO FILHO, S. T. L. et al. Agenesia unilateral de corno uterino em cadela - Relato de caso. Arquivos de Ciências Veterinárias e Zoologia, v. 4, n. 1, p. 77-79, 2001

RIBEIRO, H. F. L. Diagnosis of investigative pathology in the genital tract of buffaloes raised extensively in the State of Amapá, Amazon, Brazil. Revista Brasileira de Medicina Veterinária, v. 38, n. 4, p. 358-364, 2016.

SANTOS, R. L.; NASCIMENTO, E. F.; EDWARDS, J. Sistema Reprodutivo Feminino. In: SANTOS, R. L.; ALESSI, A. C. Patologia Veterinária. São Paulo: Roca, cap. 14, 2016. p. 1206-1301.

SÔNEGO, D. A. et al. Aplasia uterina total em cadela com atrofia segmentar de vagina - Relato de caso. Acta Scientiae Veterinary, v. 46, п. 1, p. 348, 2018. 